\title{
THE HUMAN CAPITAL IN THE UNDERPRIVILEGED MOUNTAIN AREAS OF BIHOR COUNTY
}

\author{
Claudiu FILIMON* \\ University of Oradea, Department of Geography, Tourism and Territorial Planning, University St., 410087, Oradea, \\ Romania, e-mail: filimonpunct@yahoo.fr \\ Luminița FILIMON \\ University of Oradea, Department of Geography, Tourism and Territorial Planning, University St., 410087, Oradea, \\ Romania, e-mail: palelumi@yahoo.com \\ Grigore Vasile HERMAN \\ University of Oradea, Department of Geography, Tourism and Territorial Planning, University St., 410087, Oradea, \\ Romania, e-mail: grigoreherman@yahoo.com
}

\section{Lavinia Daiana GARAI}

$\mathrm{Ph} . \mathrm{D}$. candidate, University of Oradea, Department of Geography, Tourism and Territorial Planning, University St., 410087, Oradea, Romania, e-mail: daianagarai@yahoo.com

Citation: Filimon, C., Filimon, L., Herman, G. V., \& Garai, L. D. (2019). The Human Capital in the Underprivileged Mountain Areas of Bihor County. Analele Universităţii din Oradea, Seria Geografie, 29(2), 181-193. https://doi.org/10.30892/auog.292118-825

\begin{abstract}
The current study captures the quantitative and qualitative features of the human capital in Underprivileged Mountain Areas from Bihor county, from the perspective of the human component that plays a major role in the preservation and development of these areas, both from natural and human point of view. The planned study focuses on the quantitative features (the number of population and the exerted pressure) and the qualitative ones (age and gender group structures, employed population and its distribution on branches of activities, the level of education) analysed for the year 2011 (data provided by the latest census). The analysis of these parameters highlights the fact that, from the human capital perspective, The Underprivileged Mountain Area corresponds to the demographic state of the county and the risk of depopulation is not poignant at the moment.
\end{abstract}

Key words: human capital, Underprivileged Mountain Area, population number, depopulation

$$
* * * * * *
$$

\section{INTRODUCTION}

At present, the mountain areas constitute a landmark in the political, socio-economic and scientific dialogues which take place at global level, precisely due to their natural, climatic, economic, social, cultural characteristics and their vulnerability, as well. 
Furthermore, the importance and role of mountain areas have been highlighted both in scientific studies (the well-known French academic journal Revue de Géographie Alpine is a symbol of these) and also in official documents (reports, laws, recommandations). Last but not least, there are national and international associations established to preserve and protect these vulnerable natural environments (Borsdorf and Braun, 2009). Agenda 2, in the second section addresses the 13th chapter to the management of vulnerable ecosystems, namely the mountain areas. In 2003, in Quito, Ecuador was launched the Charter for World Mountain People approved by 40 countries. The objectives pursued in both documents mentioned are the research of all existent components and resources, the aim being the preservation of the mountain environment regarded as a mandatory condition for the survival of the global ecosystem (Rey, 2007). Moreover, the most entitled international body and the main funder of programmes dedicated to the improvement of the environmental state Global Environment Facility (GEF) perceives the moutain areas as "one of the high-priority ecosystems for the preservation of biodiversity"(Borsdorf and Braun, 2009, p.104).

Last but not least, the protection, preservation and development of mountain areas, especially the underprivileged ones, constitute a major coordinate of the European Union development policy. The concerns for protecting the mountain areas have old roots throughout the Europen countries, the legislation regarding the moutain issued by France and Italy being of reference (Borsdorf and Braun, 2009). 1994 represents a key moment when in Chamonix, France was organised the first European Conference of mountain regions, led by the European Council when the European Charter of Mountain Regions was promoted.

The European policy of development lays great emphasis on mountain areas, a large number of documents and reports targeting them. A revealing example in this respect is the 1257/1999 Regulation of CE regarding the aid for rural development.

The ESPON 2004 report concerning mountain regions in Europe makes a relevant radiography of mountain areas. Chapter 5, Demographic tendencies in mountain regions, is dedicated to human resources (ec.europa.eu/regional..../montagne/mount1_fr.p).

In this European context, favourable for the preservation and development of mountain areas, shall be recorded the protection and preservation measures of underprivileged mountain areas in Romania. The Strategic Concept for Territorial Development Romania, 2030, drawn based on Europe Strategy 2020, mentions ,the planning management policy has to pay special and appropriate attention to the preservation and development of mountain regions" p. 11.

Under Law 351/2001 concerning the National Territorial Plannig (Locality network section) and Order 355 from 10 May 2007, respecting the requirements of the CE 1257/ 1999 Regulation, in Romania there were delimited the territorial units declared Underprivileged Mountain Areas, applying the European criteria. Another important step was the amendment of Mountain Law 347/2004 by the Emergency Act (OU 21 from 27.02. 2008) to harmonise the European and Romanian support and protection policy.

Under the above mentioned law, in 2007, in Romania were identified and declared as such, 657 territorial units (municipalities, towns and communes) located in 27 counties. The Underprivileged Mountain Areas in Romania cover a surface of $71340 \mathrm{~km}^{2},(22,93 \%$ of the country's surface) inhabited by 2400000 people, representing $11 \%$ of the total population.

In Bihor county, the Underprivileged Mountain Areas cover a surface of $1884,2 \mathrm{~km}^{2}$ that comprises 19 territorial units (3 towns, 16 communes), grouping a number of 56297 inhabitants, approximately $10 \%$ of the county's population in 2011 (figure 1). One of the fundamental component of the mountain system is represented by the population who lives in this restrictive and vulnerable area and who faces several hardships such as the exodus of population, impoverishment and not least the loss of cultural identity. 


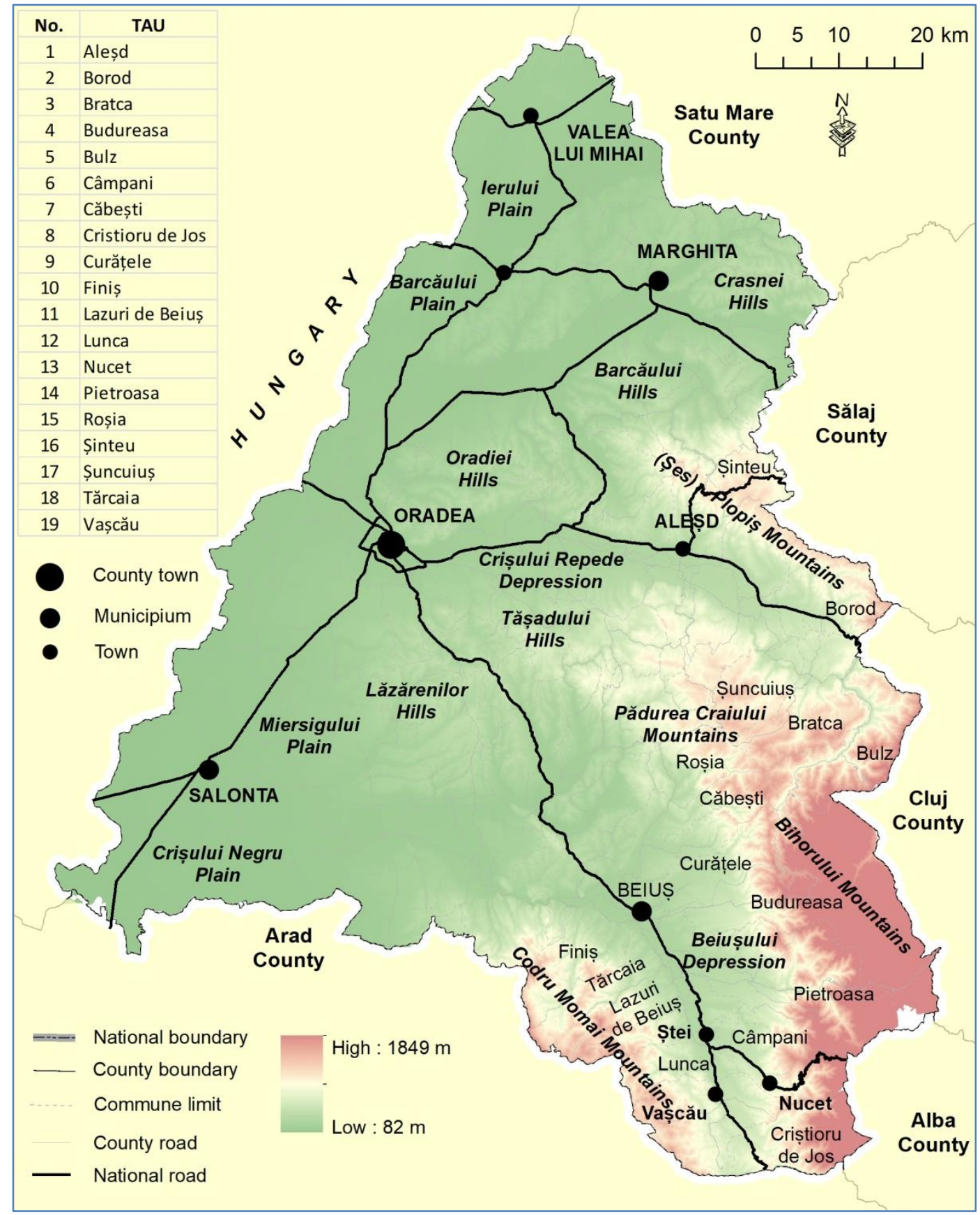

Figure 1. Underprivileged Mountain Areas in Bihor county

At present, the research carried out wants to demonstrate the fact that one of the main pillars, perhaps primal, which has to sustain the preservation/development policies in undeprivileged mountain areas, is the human capital who, by the qualitative and quantitative features and way of management could be the savior or the destroyer of the mountain. 
The approach of these territories from the human capital perspective, that generates production and consumption as well in this space, is a sensitive one because, unlike other areas, underprivileged mountain areas suffer from natural drawbacks which cannot be overcome, and also structural disadvantages (distance from the decision-making centers, deficient technical and building stock infrastructure), all of them having a direct impact on human behaviour, the guarantor for the development of any area.

\section{METHODOLOGY}

The mountain areas have always generated the reserachers' interest from varied fields, especially geographers'. In this respect, we mention in direct connection with the aimed area, the studies about the demographic risks in Apuseni Mountains (Surd et al., 2007; Filimon and Filimon, 2011; Mureșan, 2014), the mining brownfields with emphasis on tourism development (Morar, 2012, 2013), population, settlements, tourist activities (Filimon et al., 2009, 2011; Filimon, 2014; Herman and Benchis, 2017; Herman et al., 2019; Lung and Gligor, 2018; Lung, 2019; Novac, 2006; Stașac et al., 2016). The main objective is the analysis and highlight of the human capital in the Underprivileged Mountain Areas associated to Bihor county. To reach this goal, some relevant and widely used parameters have been selected (Lecaillon, 1992; Dumont, 2012; The ESPON report, 2011; The European Commission, 2011; SIESTA, 2014). Therefore, to capture the quantitative and qualitative characteristics of the human capital, we used the following parameters: number of population, gender structure, age-group structure, employed population and distribution on sectors of activity. Another indicator was the population level of education, which indicates the quality and the perspectives of human capital. These parameters were analysed using data supplied by the population census from 2011.

\section{RESULTS AND DISCUSSIONS}

The number of population is the direct result of its numerical evolution throughout time. Naturally, over time, the total number of population in the Underprivileged Mountain Areas registered fluctuations determined by a number of factors: demographic, social, political, historical and natural ones. The number of population offers not only a real image regarding the existent demographic potential, but also the pressure exerted on the natural environment, by the density values.

The total population registered at the last census, in 2011, in the studied area is 56297 inhabitants, representing $9,9 \%$ of the county's total population. At territorial level, there are major differences between communes and towns, recording a maximum of over 10000 inhabitants in Aleșd town and a minimum of 1021 inhabitants in Șinteu commune (table 1). In fact, within the area, with the exception of Aleșd, only five territorial units register a population of over 3000 inhabitants, an average value for the communes in the country. The other communes, including Nucet and Vaşcău towns, register lower values of the population.

Table 1. Total population and population density in the Underprivileged Mountain Area in Bihor county

\begin{tabular}{|c|c|c|c|c|}
\hline No. & TAU & $\begin{array}{c}\text { Population } \\
\text { number }\end{array}$ & $\begin{array}{c}\text { Surface } \\
\left(\mathbf{k m}^{2}\right)\end{array}$ & $\begin{array}{c}\text { Population density } \\
\left(\mathbf{i n h a b} . \mathbf{k m}^{2} \mathbf{)}\right.\end{array}$ \\
\hline 1 & Aleșd & 10006 & 72,45 & 138,9 \\
\hline 2 & Borod & 3843 & 105,62 & 36,4 \\
\hline 3 & Bratca & 5158 & 136,48 & 37,8 \\
\hline 4 & Budureasa & 2581 & 346,46 & 7,4 \\
\hline 5 & Bulz & 2104 & 99,39 & 21,2 \\
\hline 6 & Câmpani & 2427 & 44,49 & 54,6 \\
\hline 7 & Căbești & 1848 & 71,18 & 26,0 \\
\hline 8 & Criștioru de Jos & 1354 & 101,71 & 13,3 \\
\hline 9 & Curățele & 2509 & 91,10 & 27,5 \\
\hline 10 & Finișis & 3680 & 104,70 & 35,1 \\
\hline
\end{tabular}




\begin{tabular}{|l|c|c|c|c|}
\hline 11 & Lazuri de Beiuș & 1518 & 58,92 & 28,5 \\
\hline 12 & Lunca & 2887 & 69,61 & 41,5 \\
\hline 13 & Nucet & 2165 & 41,11 & 52,7 \\
\hline 14 & Pietroasa & 3209 & 205,35 & 15,6 \\
\hline 15 & Roșia & 2384 & 72,52 & 32,9 \\
\hline 16 & Șinteu & 1021 & 49,33 & 20,7 \\
\hline 17 & Șuncuiuș & 3259 & 72,04 & 45,2 \\
\hline 18 & Tărcaia & 1969 & 76,70 & 25,7 \\
\hline 19 & Vașcău & 2315 & 65,04 & 36,5 \\
\hline 20 & Total area & $\mathbf{5 6 2 9 7}$ & $\mathbf{1 8 8 4 , 2}$ & $\mathbf{2 9 , 9}$ \\
\hline
\end{tabular}

Regarding the exerted pressure, looking at the population density values we can state that the degree of anthropization is low, the average density value being that of 29,9 inhab. $/ \mathrm{km}^{2}$, which is under the national average for the mountain areas, 33,6 inhab. $/ \mathrm{km}^{2}$. The values registered in the administrative units range between a maximum of 138,9 inhab. $/ \mathrm{km}^{2}$ in Aleșd and 7,4 inhab. $/ \mathrm{km}^{2}$ in Budureasa. This should not come as a surprise since Budureasa commune has the biggest surface and Aleșd is among the units with relatively small territorial surface.

\section{Gender structure}

It is highly important because it offers information regarding the balance between genders. Moreover, it represents the foundation for the demographic policies and contributes crucially to the development of certain activity sectors (Filimon, 2014). From the total population in the territorial units from the area, the female population represents $50,7 \%$ (28 586 people), and the male population is 49,3\%, 27711 people, respectively. It can be noticed that, from this point of view, there is a certain balance between the genders, this situation is explainable by the mountainous character of the area and the economic activities typical for men. The male over-mortality occurs over the age of 60 . Obviously, at the level of administrative units there are differences generated by specific situations (figure 2). Thereby, the male popualtion holds higher values compared to the female population in some communes: Roșia 51,7\%, Căbești 50,3\%, and in Șuncuiuş and Șinteu communes there is a balance between the genders. These exceptions are explained by the specific of the existent economic activities, mining and wood exploitation, which influence the population gender structure. The lowest levels of the male population are registerd in Vașcău, 47,9\%, generated by the industrial restructuring and Tărcaia, 48\%, due to agricultural activities (vegetable growing).

\section{Age-group structure}

The function of an area is closely connected to the population age-group structure, which determines the workforce potential, educational activities, the organization of certain services, especially those of health, and not least the consumption.

The distribution of population on the three major age groups, 0-14 years old, 15-59 years old and 60 and over 60 years old, highlights some characteristics (figure 3 ). The largest proportion is registered by the adult population 15-59 years old, 33422 people, 59,2\% from the total population respectively. This age-group generated the workforce and the biologic potential of the studied area. With higher values than the average are the towns Aleșd and Nucet and several communes: Bulz, Câmpani, Finiș, Pietroasa, Șinteu, Tărcaia, all with a percentage of over $60 \%$. These higher values are due to the fact that the first are towns and in the communes the economic activities carried out (agricultural, agropastoral and tourism) contribute to the population stability.

The young population is the most diminished numerically, 9199 people, representing $15,3 \%$ of the total population. This low value is the result of the process of demographic aging, social-ecomonic changes and a new approach to the idea of family with direct influence on this age group. Even if most of the territorial units are within the average for this area, there are some 
with values over the average. This is the case of Finiș $(21,2 \%)$, Borod, Bratca, Budureasa, Roșia, Șuncuiuș communes and the town Aleșd with over 18\%. The explanation for these higher values lies in the recovery of the economic sector in these areas, reinforced by the presence of some communities with a different demographic behaviour from that registered at general level (pentecostals in Finiş, gypsies/Romani people in Șuncuiuş, Pietroasa).

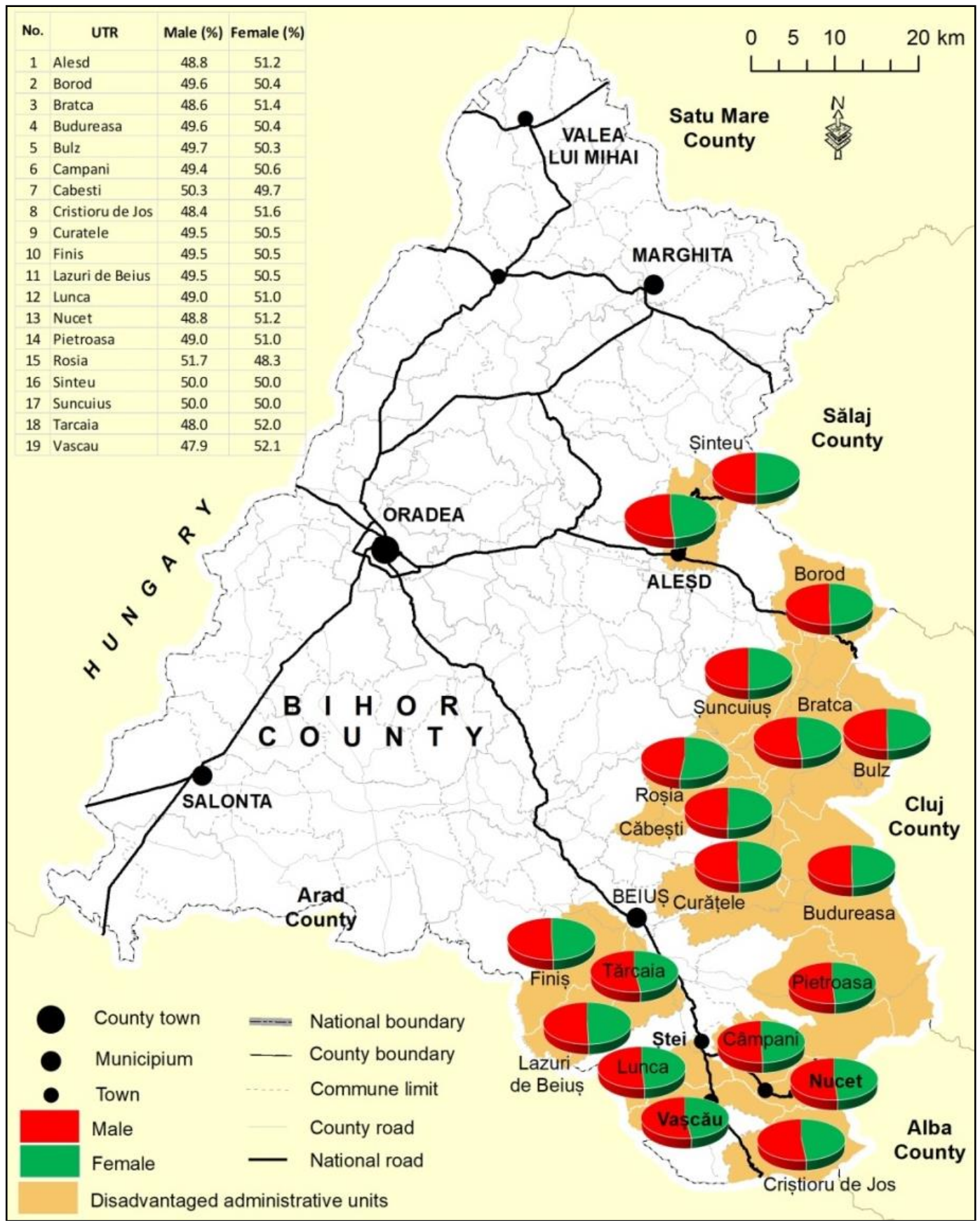

Figure 2. Population gender structure 


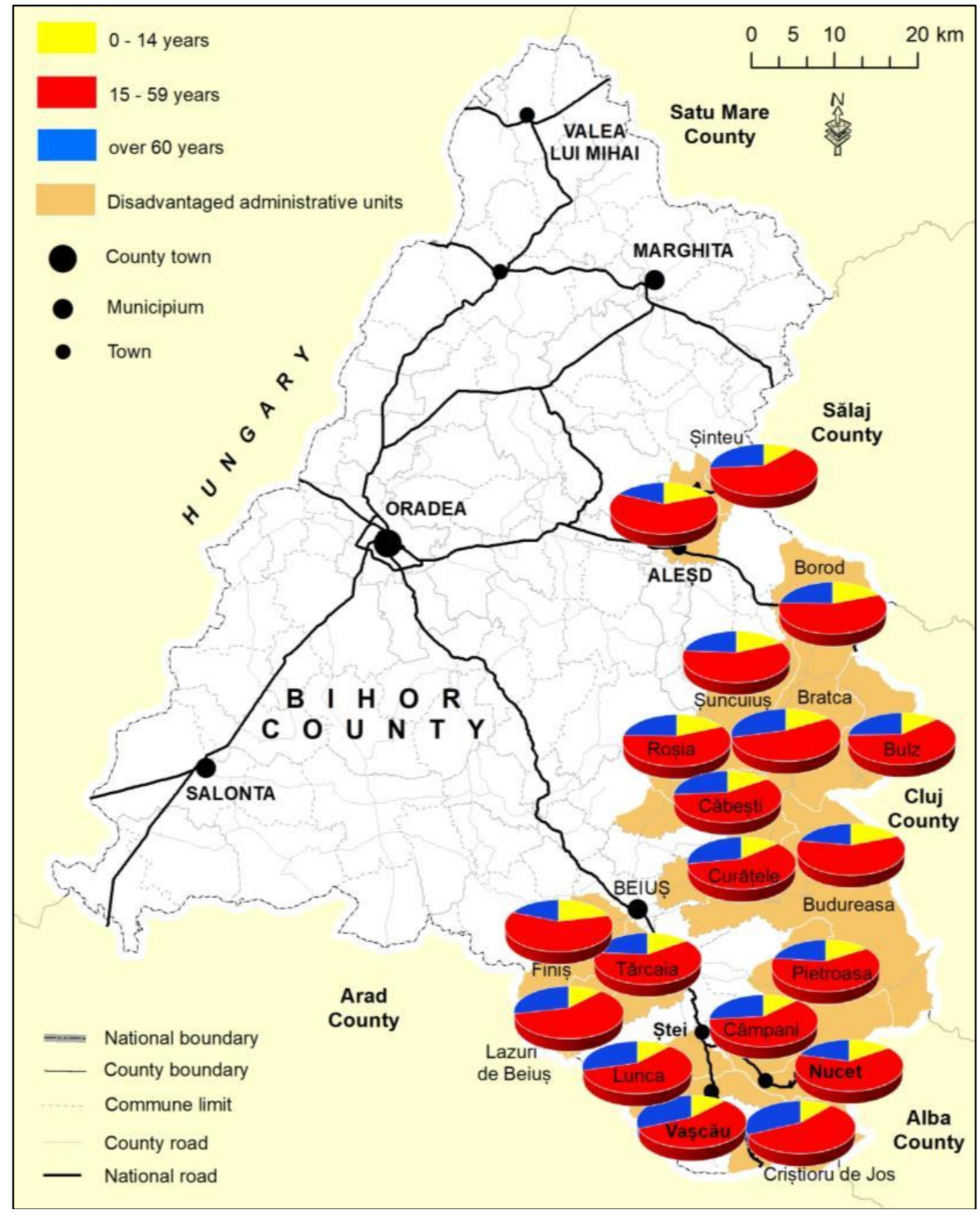

Figure 3. Structure on major age-groups

The elderly population numbers 13674 people, meaning 25,5\% of the total population, a value much higher than the one registered at county level $(21,1 \%)$. It has to be noted that, in this group, the highest proportion is registerd by the female population, with a percentage of $60 \%$.

The low level of economic and social attractiveness of the mountain space for the young population and the outward migration influence the values registered by the elderly and the 
process of demographic aging. The territorial constraints amplified by the socio-economic situation is very-well exemplified by the two extremes: the town Aleșd with a low percentage of old population, 18,1\%, and the commune Criștioru de Jos and the town Vașcău with highest percentage of old population, over $31 \%$, respectively.

\section{Employed population}

Being dependent on th socio-economic climate and level of development, the emplyed population reflects the concentration way and development status attained by the production forces, becoming a reference in the functional definition of the communities. At the level of the entire Underprivileged Mountain Area, the employed population represents 23453 people, 41,7\% from the entire active population, value which corresponds to the value recorded at county level $(41,8 \%)$. From all the territorial administrative units, in 8 of them the registered values are above the average, with a maximum of $70,9 \%$ in Șinteu commune (figure 4 ).

The lowest value is registered in Finiș commune, where the employed population represents a percentage of $28,2 \%$. It is worth mentioning the fact that in all the three towns located in the area the proportion of employed population is under the overall average, a fact that emphasises the different mentality in the rural space towards work compared to the population in the urban areas under the new socio-economic conditions.

Closely linked to the employed population is the population structure on sectors of activity. This parameter is the one that defines, to a large extent, the functional profile of the respective community.

The distribution of employed population on the three sectors of activity highlights the profound rural character of the Underprivileged Mountain Area. Therefore, the proportion of population in the primary sector is $48,3 \%$, value which demonstrates the economic dependence on agricultural activities of the population. As it can be noticed, (figure 5) in the studied territory there are differences at the level of units. The highest level is registerd in Șinteu commune, 85,5\%, a reflexion of its economic past and present, centered on agricultural activities. Except for the three towns Aleșd (9,2\% the lowest value), Nucet and Vașcău, only in three communes the values are under the average: Finiș, Lunca and Șuncuiuș.

The population employed in the secondary sector, 4092 people, represents only $16,4 \%$ from the employed population. This value is disproportional compared to the existent natural resources which allow the development of this activity. An important role in this value, is taken by the changes occurring in industry in the post communist period. The most remarkable values are registered in the towns Vașcău (31,9\%), Aleșd (30,8\%), Nucet $(23,8 \%)$, as an effect of the existent industrial tradition and European Food and European Drinks industrial platforms. In the rural area, we can notice the communes Lazuri de Beius,, Lunca and Pietroasa with over $20 \%$, an effect of the above mentioned industrial platforms located in the vicinity.

The tertiary sector represents 35,3\% of the entire employed population. The proportion of employed population in this sector has registered constant increases after 1990, free economic enterprise being no longer forbidden. We have to mention the fact that the employed population plays an important role in public services, followed by constructions, commerce, tourism. The highest values are registered in the towns Aleșd (60\%) and Nucet (59,2\%), located far away from the other territorial units. These values are the result of their town status and activities in the fields of commerce, tourism, construction. The tourist activities are seconded by the commercial ones in the communes Suncuiuș $(54,6 \%)$, Bratca $(39,1 \%)$, Bulz $(36,1 \%)$ and by constructions in Finiș $(42,7 \%)$, this fact placing these communes with values above the overall average. In the other administrative units, the registered values are inferior or close to the overall average.

The population level of education is of primary importance in the qualitative definition of population and workforce, in particular. Out of the total population of 10 and over, the highest proportion $66,7 \%$ is registered by the population with secondary studies, $18,3 \%$ primary studies, $7,3 \%$ higher education $3,3 \%$ post-secondary and vocational, and a percentage of $4,4 \%$ has no 
studies (figure 6). These values reflect on the field the aging demographic process, the predominantely rural character of the area and the economic specificity.

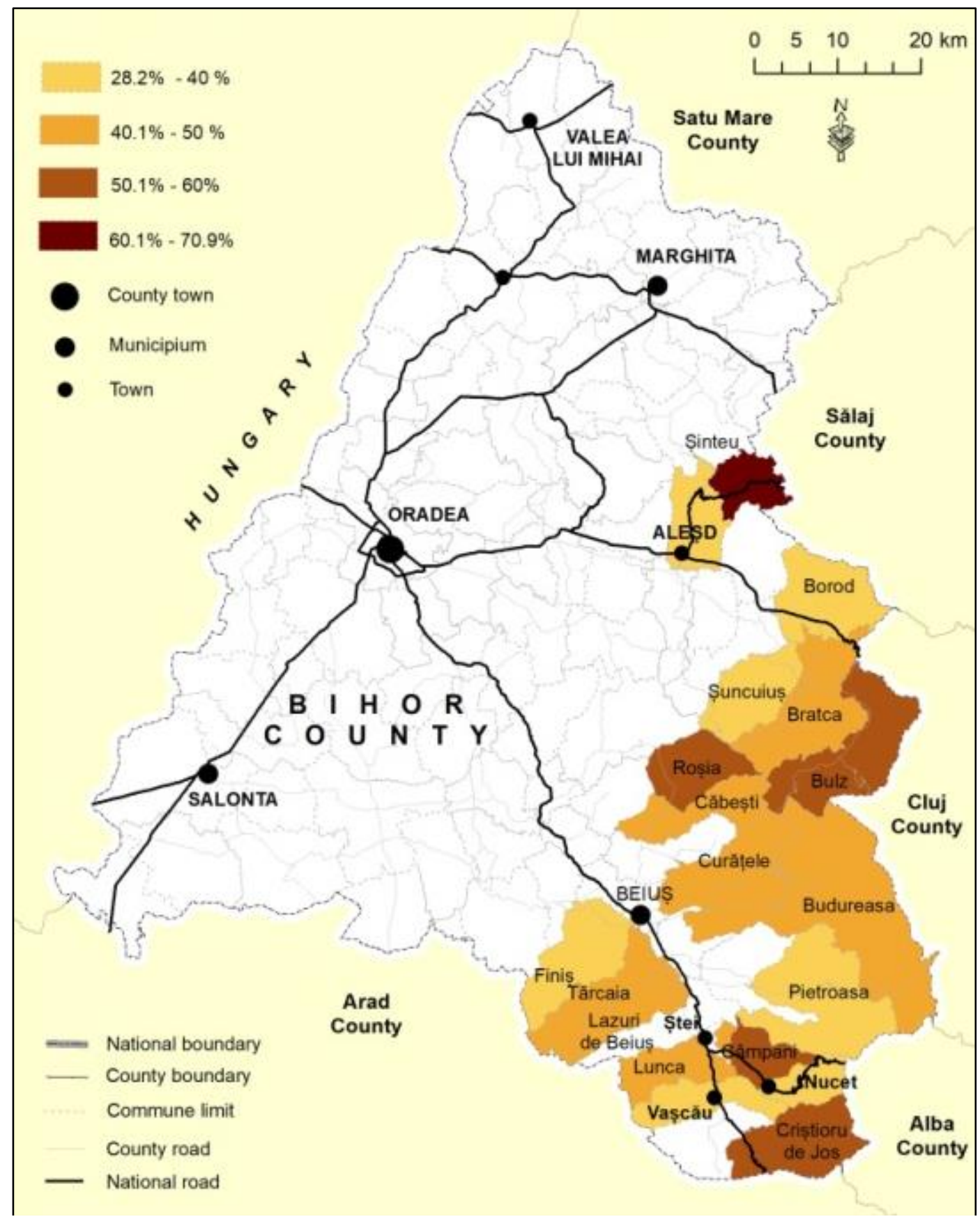

Figure 4. The proportion of employed population 


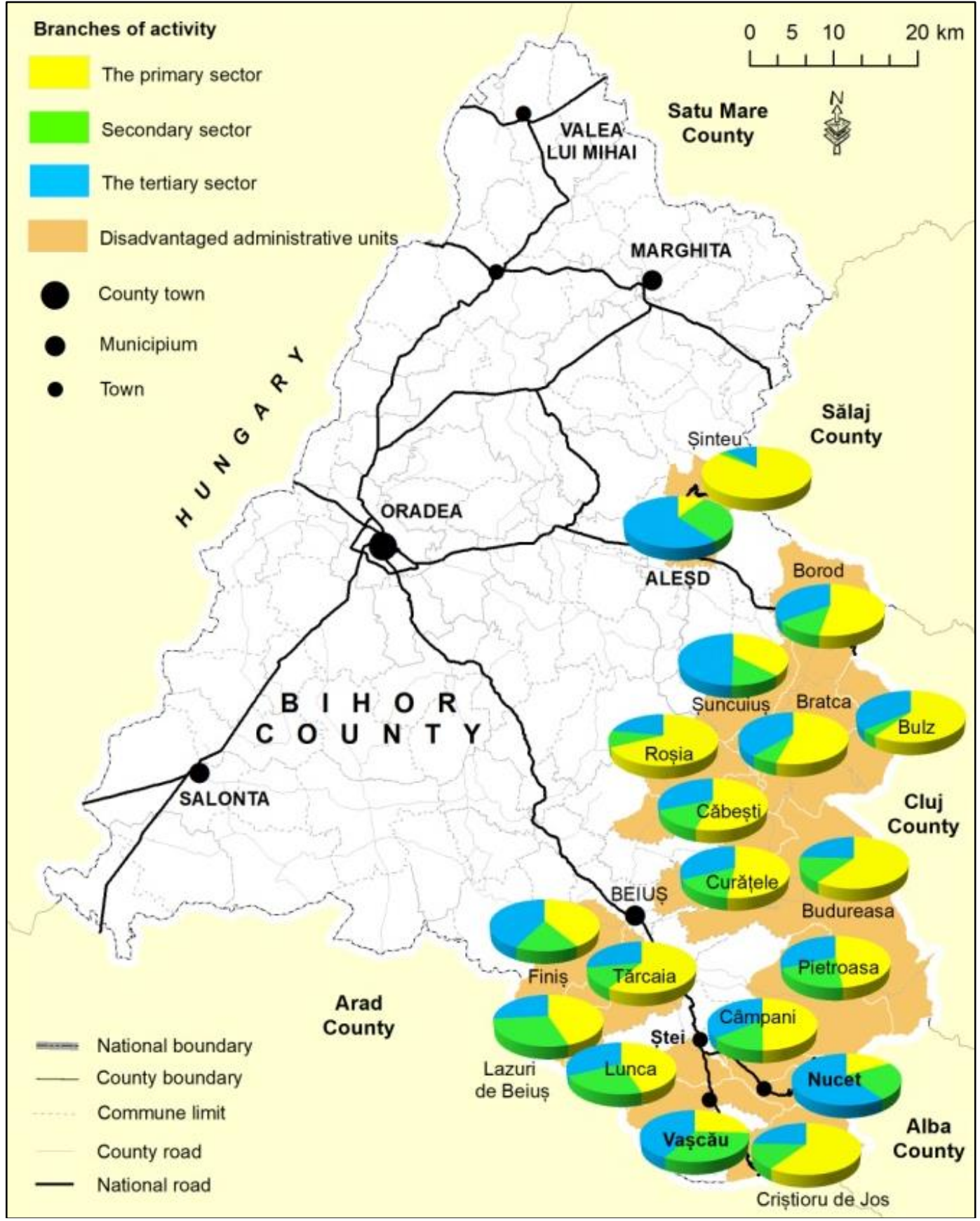

Figure 5. The employed population on sectors of activity 


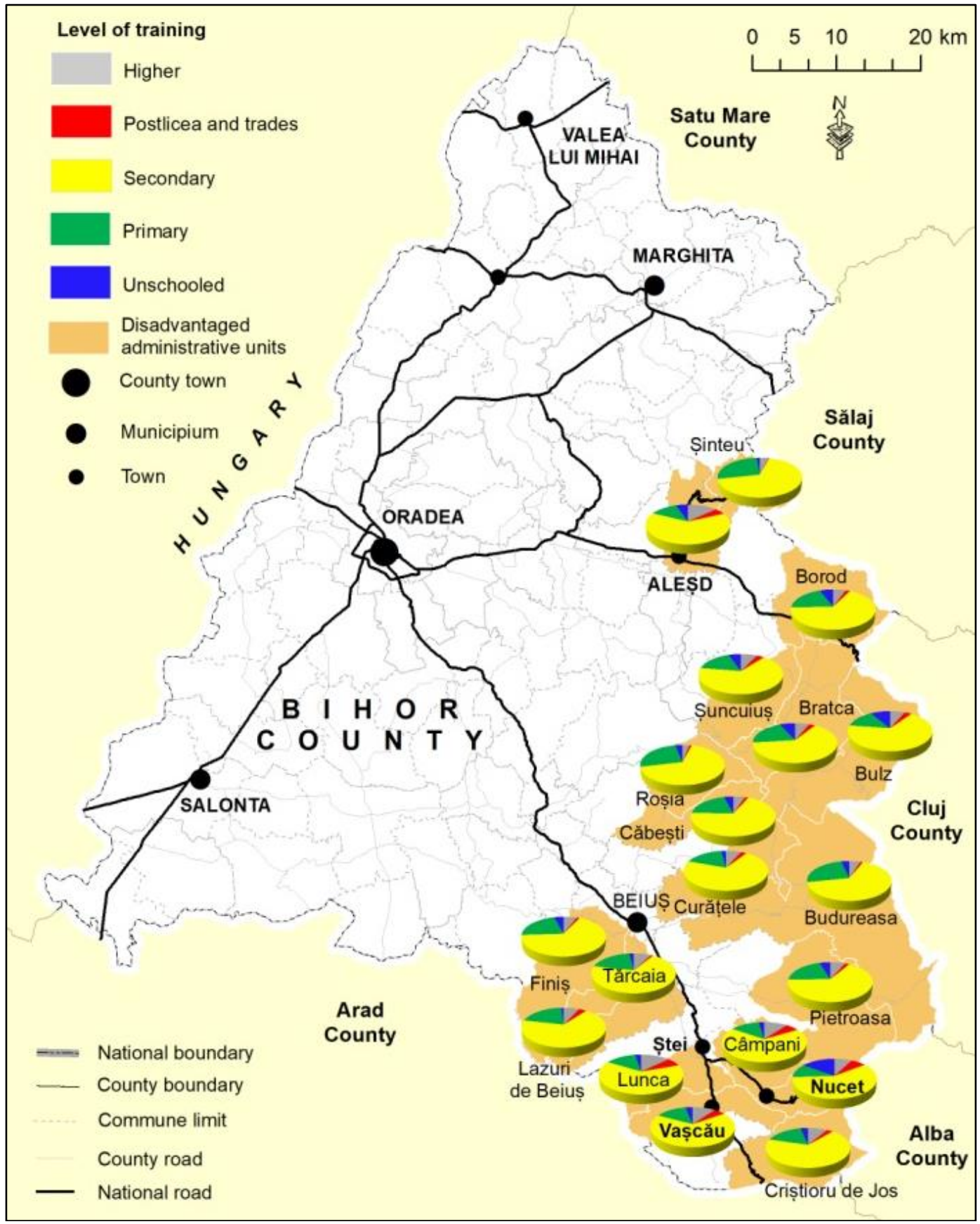

Figure 6. The population level of education

The people with secondary studies (high school and middle school) register the highest values in Curățele commune, $71 \%$, on the opposite side being the town Nucet with $59,6 \%$ from the population of 10 and over.

A number of 4090 people, 7,3\% respectively attended higher education. The low percentage is normal for a mountain area, generally seen repulsive by those with higher studies. In addition, the 
existent economic activities do not require such studies. Values above the average are registered in Aleșd (13,1\%), followed by Vaşcău and the communes Lunca and Câmpani, with over $10 \%$. Postsecondary and vocational studies do not register important proportions, 1661 people, or 3,3\% respectively. Higher values are recorded in the towns Nucet $(6,7 \%)$, Vaşcău $(5,1 \%)$ and Aleşd $(5 \%)$, and among the communes Lunca $(6,7 \%)$ and Câmpani (6\%) have been noticed.

8854 people attended primary studies who represent $18,3 \%$ of the population of over 10 years old. At territorial level, the highest value is registered in Şinteu, 27,1\%, and the lowest value is recorded in Nucet with $11 \%$.

The lack of studies characterises a number of 2435 people, $4,4 \%$ of the population of school age. The territorial units where the illiterate people register higher proportions are either more isolated with a larger elderly female population Bulz $(8,8 \%)$, Bratca $(6,8 \%)$ or communities with a significant number of gypsies/Romani people such as the one from the commune Șuncuiuș $(5,4 \%)$.

\section{CONCLUSIONS}

The analysis of the human capital in the Undeprivileged Mountain Area of Bihor county allows the sketch of an overview and the emphasis of some significant aspects, which place the human resources close to the demographic specificity of the county.

Quantitatively, we can state that the population volume is low compared to the natural potential and the dwelling capacity offered by the mountain area in Bihor county. Another relevant aspect lies in the fact that, in number and density, the population does not represent a pressure factor on the mounatin.

Regarding the quality of the human resources, it can be noticed a certain balance between the two genders, more male inhabitants than female being present in few administrative units (Roșia, Căbești).

The distribution of population on age groups highlights the fact that the recorded values by the three main groups are within the normal values recorded at county level. The process of demographic aging, at least for now, is not significant and does not endanger the existence of communities.

The employed population and its distribution on sectors of activity emphasise the rural character of this area and its high dependence on the activities in the primary sector, the nonagricultural activities being less present.

The level of education is according to the needs in underprivileged mountain areas and it contributes to the emphasis of the predominantly rural character of this space.

\section{REFERENCES}

Borsdorf, A., \& Braun, V. (2008). The European and global dimension of mountain research. An Overview. Journal of Alpine Research| Revue de géographie alpine, (96-4), 117-129.

Dumont, G. F. (2012). Diagnostic et gouvernance des territoires: concepts, méthode, application. Hachette.

Filimon, C., \& Filimon, L., (2011). Communities between preservation and disappearance: the demographic hazard in Beiuş Land. Analele Universitatii din Oradea, Seria Geografie, 21(2), 276-285.

Filimon L., Chiriac, C., Petrea, R., \& Filimon, C., (2009). Population Mobility and its Implications in Territorial Reconversion. a Case Study: The Crisul Repede Valley Territorial Planning Unit. Analele Universităţii din Oradea, Seria Geografie, 19, 163-170.

Filimon, L., Petrea, R., Petrea, D., \& Filimon, C. (2011). Small towns and intercomunal construction. Case study: Bihor county, Romania. Transylvanian Review of Administrative Sciences, 7(34), 114-126.

Filimon, C. (2014). Depresiunea Oradea-Bratca. Studiu de populaţie şi aşezări [Oradea-Bratca Depression. Population study and settlements]. Presa Universitară Clujeană, Cluj Napoca (in Romanian).

Herman, G.V., \& Benchiş L., B., (2017). Fairs, Forms of Expression the Local Identity. Case Study: Beius Fair, Bihor County, Romania. Analele Universitatii din Oradea, seria Geografie, 27(1), 108-113.

Herman, G.V., Varodi, M.O., Grama, V., \& Morar, C. (2019). Geographical Considerations Regarding the Tourist Destination Pădurea Craiului Mountains. Analele Universităţii din Oradea, Seria Geografie, 29(1), 102-108.

Lecaillon, J. D., (1992). Demographie economique. Analyse de ressources humaine, Deuxieme edition. Edition Litec, Paris. 
Lung, M. S., \& Gligor, V., (2018). Demographic Changes in the Urban Space of Apuseni Mountains. Analele Universitatii din Oradea, Seria Geografie, 28(2), 164-173.

Lung M.-S. (2019). Continuity and Demographic Cycling in the Romanian Carpathian Space in the Period 1930-2011. Analele Universităţii din Oradea, Seria Geografie, 29(1), 79-91.

Morar, C. (2012). Demographic Characteristics of the Disdavantaged Mining Areas in the Bihor County, Romania. Analele Universităţii din Oradea, Seria Geografie, 22 (1), 163-174.

Morar, C., (2013). Turism şi dezvoltare regională durabilă în zonele miniere defavorizate din judeţul Bihor [Tourism and sustainable regional development in the underprivileged mining areas of Bihor County], Editura Universităţii din Oradea, Oradea (in Romanian).

Muresan, G.-A. (2014). Geodemographic risks within the Apuseni Mountains, Studia UBB Geographia, 59 (1), $117-126$.

Novac, I. (2006). Munţii Pădurea Craiului. Studiu de Geografie rurală [Pădurea Craiului Mountains. Study of Rural Geography], Editura TIPO MC, Oradea (in Romanian).

Rey, R. (2007). Carpaţii României la o răscruce a istoriei [The Carpathians of Romania at the crossroads of history]. Nevoia unei strategii de dezvoltare montană durabilă şi a unei politiici montane aplicată constant - În contextul provocărilor climatice şi demografice ale secolului XXI, Colocviul româno-spaniol Economie şi cultură, SibiuPăltiniş. www. ince.ro/ProbReyPdf (in Romanian).

Surd, V., Zoric, V., Puiu, V., Moldovan, C., (2007). Riscul demografic în Munţii Apuseni [Demographic risk in the Apuseni Mountains], Presa Universitară Clujeană, Cluj-Napoca (in Romanian).

Stașac, M., Filimon, C., Petrea R., Bulzan A., (2016). The Demographic Behaviour of Small Towns in Romania in the Post-Communist Period Analyzed Through the Dynamics of the Population. Case Study: The Small Towms in the Bihor County, Romania. Analele Universităţii din Oradea, Seria Geografie, 26 (2), 210-222.

*** (2011). Raportul ESPON [The ESPON report], Interco-Indicatori ai coeziunii teritoriale, on-line la http://www.espon.eu/main/Menu_Projects/Menu_ScientificPlatform/interco.html (in Romanian).

*** (2011). Comisia Europeană [The European Commission], Fişa informativă Dezvoltarea locală plasată sub responsabilitatea $\begin{array}{llllll}\text { comunităţi, } & \text { Politica } & \text { De } & \text { Coeziune } & \text { on-line } & \text { la }\end{array}$ http://ec.europa.eu/regional_policy/sources/docgener/informat/2014/community_ro.pdf (in Romanian).

(2014). Spatial Indicators for $\mathrm{a}^{\prime}$ Europe 2020. Strategy Territorial Analysis (SIESTA), https://www.espon.eu/programme/projects/espon-2013/applied-research/siesta-spatial-indicators-europe-2020-strategy.

Submitted:

July 22, 2019
Revised:

November 27, 2019
Accepted and published online

December 19, 2019 